\begin{tabular}{|l|l|l||}
\hline \multicolumn{2}{|c|}{ PublisherInfo } \\
\hline \hline PublisherName & $:$ & BioMed Central \\
\hline \hline PublisherLocation & $:$ & London \\
\hline \hline PublisherImprintName & $:$ & BioMed Central \\
\hline \hline
\end{tabular}

\title{
TARC attenuates the development of asthma in mice
}

\begin{tabular}{|c|c|c|}
\hline & & IrticleInfo \\
\hline ArticleID & : & 1617 \\
\hline ArticleDOI & : & $10.1186 / \mathrm{rr}-2001-68533$ \\
\hline ArticleCitationID & : & 68533 \\
\hline ArticleSequenceNumber & : & 28 \\
\hline ArticleCategory & : & Paper Report \\
\hline ArticleFirstPage & : & 1 \\
\hline ArticleLastPage & : & 4 \\
\hline ArticleHistory & : & $\begin{array}{ll}\text { RegistrationDate } & : 2001-9-18 \\
\text { Received } & : 2001-9-18 \\
\text { Accepted } & : 2001-9-18 \\
\text { OnlineDate } & : 2001-3-7\end{array}$ \\
\hline ArticleCopyright & : & Biomed Central Ltd2001 \\
\hline ArticleGrants & & \\
\hline ArticleContext & & 129312211 \\
\hline
\end{tabular}


Yassine Amrani, ${ }^{\text {Aff1 }}$

Corresponding Affiliation: Aff1

Aff1 University of Pennsylvania Medical Center, Philadelphia, PA, USA

\section{Keywords}

Airway inflammation, allergen, $\mathrm{CD} 4^{+}$lymphocytes, chemokines, eosinophils, eotaxin, TARC

\section{Context}

Evidence now suggests that chemokines such as RANTES (regulated on activation normal T cell expressed and secreted) and eotaxin may play an important role in mediating lung inflammation in asthma. However, the precise nature of the different chemokines involved is not fully defined. Thymusand activation-regulated chemokine (TARC), which specifically binds to the $\mathrm{CC}$ chemokine receptor 4 (CCR4), is an interesting candidate as it regulates the chemotaxis of $\mathrm{CD}^{+} \mathrm{T}$ lymphocytes that are active cells in the pathogenesis of asthma. In this study, the authors investigated whether TARC is involved in the development of airway inflammation and airway hyperresponsiveness (AHR) in a mouse model of asthma.

\section{Significant findings}

TARC mRNA levels in the lungs increased significantly at 3, 6, 24 and $48 \mathrm{~h}$ after allergen challenge. Immunohistochemical staining also showed an increased expression of TARC protein in lung sections of allergen-challenged mice, with staining mainly located in the bronchial epithelium and endothelium. When compared to control antibody anti-TARC antibody blocked the OVA-induced increase in eosinophils and $\mathrm{CD}^{+}{ }^{+} \mathrm{T}$ lymphocytes in both bronchoalveolar lavage (BAL) and lung tissue. AntiTARC antibody also abrogated the elevated production of interleukin (IL)-4, IL-13 and interferon-g found in BAL and the increase in eotaxin gene expression found in the lung of OVA-challenged mice. Finally, the anti-TARC antibody resulted in a $64 \%$ inhibition of allergen-induced increases in AHR to methacholine. Collectively, these data showed the involvement of TARC in regulating eosinophilia and AHR in an animal model of asthma. 


\section{Comments}

The proteins RANTES and eotaxin may be involved in the pathogenesis of asthma by recruiting inflammatory cells within the airways. Here, the authors found no significant increase in RANTES expression in the lung of OVA-challenged animals contrasting with a previous report showing a potential role of RANTES in allergen-induced leukocyte infiltration in the airways of a murine model of asthma (see Additional information). In this study, however, TARC was found to play a major role in the accumulation of eosinophils and $\mathrm{CD}^{+}{ }^{+} \mathrm{T}$ lymphocytes in the lungs of allergen-challenged mice, possibly through effects on the expression of Th2-type cytokines and eotaxin. The precise mechanism by which TARC is upregulated after allergen challenge has not been addressed here but the study demonstrates that the airway epithelium and endothelium are the most important cellular sources of TARC in the airways. As TARC modulates both airway inflammation and BHR, targeting TARC synthesis or activity in these cell types may offer new insights in the design of new treatments for asthma.

\section{Methods}

Animal sensitization, RT-PCR, immunostaining, ELISA, airway responsiveness

\section{Additional information}

Gonzalo JA, Lloyd CM, Wen D, Albar JP, Wells TN, Proudfoot A, Martinez-A C, Dorf M, Bjerke T, Coyle AJ, Gutierrez-Ramos JC: The coordinated action of CC chemokines in the lung orchestrates allergic inflammation and airway hyperresponsiveness.

$J$ Exp Med 1998, 188:157-167.

\section{References}


1. Kawasaki S, Takizawa H, Yoneyama H, Nakayama T, Fujisawa R, Izumizaki M, Imai T, Yoshie O, Homma I, Yamamoto K, Matsushima K: Intervention of thymus and activation-regulated chemokine attenuates the development of allergic airway inflammation and hyperresponsiveness in mice. $\mathrm{J}$ Immunol. 2001, 166: 2055-2062.

This PDF file was created after publication. 